\title{
Seasonal Limnological Variation in Tale Pimpalgaon dam near Patoda Dist.Beed (M.S)India.
}

\author{
${ }^{1,}$ Pramod P Gaike, ${ }^{2}$ A.H.Kamble \\ ${ }^{1}$ Dept. of Zoology P V P College Patoda Dist.Beed - 414204 (M.S) India \\ ${ }^{2,}$ Dept.of Zoology Jamkhed Mhavidyalaya Jamkhed Dist-Ahemadnagar
}

\begin{abstract}
The Tale Pimpalgaon is situated near Patoda. The study of physico chemical parameters 14 parameters like temperature, pH,calcium, magnesium, bicarbonate, chloride, Sulphate, dissolve oxygen, biochemical oxygen demand, chemical oxygen demand, nitrate, phosphate, has been studied in the period of Jan 2012 to Jan 2013.The study shows that seasonal variation in the physico-chemical parameters.
\end{abstract}

Key words: Physico-chemical parameters, Tale Pimalgaon Dam, Nitrate,Phosphate

\section{INTRODUCTION} Water is an indispensable natural resource on earth. All life including human being depends on water.

We have enormous resource on the earth amounting to about 13, 481, $96000 \mathrm{Km}$ of water. Due to its unique properties water is of multiple uses for living organisms. In India 77\% of water is used in agricultural sector (1). Human being depends on water for almost every developmental activity. Water is used for drinking, irrigation, washing, and Industrial purposes. Although water is very abundant on this earth, yet it is very precious. Out of the total water reserves of the world, about $97 \%$ is salty water and only $3 \%$ is fresh water. Even this small fraction of fresh water is not available to us as most of it is locked up in polar ice caps and just $0.003 \%$ is readily available to us in the form of ground water and surface water. (2) The fresh water resources now a day as consequences of population explosion coupled with industrialization, urbanization, and green revolution. In present investigation an attempt has been made to study the impact of human activities on the surface water at Tale pimpalgaon dam. Tale Pimpalgaon dam was designed in the 2000. . The domestic use of water from reservoir is large like bathing, washing of cloths, cattle bathing, and leads to water pollution of the reservoir. For high crop yield production farmers use fertilizers, pesticides that along with rain water runoff come into the reservoir. Many hotels located along side of reservoir and from these hotels kitchen waste is also discharge in reservoir.

\section{MATERIALS AND METHODS}

The water samples were collected from Four different sites of Tale Pimpalgaon dam from the adjacent localities.. Samples were collected in sterilized screw-capped polyethylene bottles (4) having one-liter capacity, labeled properly and analyzed in laboratory for their physico-chemical parameters. Monitoring was done during January 2012 to January 2013. The sampling sites are (Fig.1) near dam wall (A ), Canal (A ) and near Spillway $\left(\mathrm{A}_{3}\right)$, Down stream dam $\left(\mathrm{A}_{4}\right)_{\text {.. }}$ The unstable parameters such as $\mathrm{pH}$, temperature, dissolved oxygen were measured in situ using sensor of water quality monitor (WQM; In-Situ Inc; Multi parameter Toll 9000). Parameters like magnesium, and bicarbonate, chloride, Sulphate, biochemical oxygen demand, chemical oxygen demand, nitrate, phosphate were analyzed according to the standard methods prescribed in literature. (58). The results obtained are reported in the results.

\section{RESULTS AND DISCCUION} The results of analysis summarized in table no. 1. During the study period, the temperature of entire reservoir ranges between $21.09^{0} \mathrm{C}$ (winter) to $22.23^{\circ} \mathrm{C}$ (post- monsoon). The $\mathrm{pH}$ of water was varying from 6.55 to 8.70 during the entire study period. . The discharge from resorts and small industries may increase the $\mathrm{pH}$ of water, where as, in monsoon, addition of rainwater diluted the effect and resulting on $\mathrm{pH}$ value. The calcium hardness of entire samples ranges between $5.27 \mathrm{mg} / \mathrm{L}$ to $19.60 \mathrm{mg} / \mathrm{L}$. The minimum values shown in winter and maximum in maximum. The bicarbonate concentration varied between $23.52 \mathrm{mg} / \mathrm{L}$ to $30.14 \mathrm{mg} / \mathrm{L}$. In monsoon bicarbonate concentration was observed to maximum value and in post monsoon showed minimum value. In the study, the values of chloride were ranging between $4.30 \mathrm{mg} / \mathrm{L}$ to $11.36 \mathrm{mg} / \mathrm{L}$. The higher chloride value observed in monsoon season while in winter season it was observed less. In the present study Sulphate concentration varied between $0.20 \mathrm{mg} / \mathrm{L}$ to $5.20 \mathrm{mg} / \mathrm{L}$. The minimum as well as maximum value was observed in winter. During the study period dissolved oxygen varied between $5.20 \mathrm{mg} / \mathrm{L}$ to $9.78 \mathrm{mg} / \mathrm{L}$. Among the all 
values it was observed minimum in begging of post monsoon and maximum in off set of post monsoon. The biochemical oxygen demand values ranges between $0.25 \mathrm{mg} / \mathrm{L}$ to $3.50 \mathrm{mg} / \mathrm{L}$. Monsoon season shows higher value and winter shown less value of BOD. Chemical oxygen demand showed much variation. It ranges between $2.22 \mathrm{mg} / \mathrm{L}$ to $16.32 \mathrm{mg} / \mathrm{L}$. The winter season showed minimum values of chemical oxygen demand were as post monsoon showed maximum value of chemical oxygen demand. The nitrate values varied between $0.46 \mathrm{mg} / \mathrm{L}$ to $1.72 \mathrm{mg} / \mathrm{L}$. Post monsoon showed the maximum value of nitrate where as minimum value observed in winter season. Phosphate value were nil at beginning of monsoon whereas post monsoon showed a maximum value of $0.49 \mathrm{mg} / \mathrm{L}$. During the monsoon, precipitation eroded the land containing fertilizer got mixed to wate monsoon. The magnesium concentration varied between $0.81 \mathrm{mg} / \mathrm{L}$ to $6.92 \mathrm{mg} / \mathrm{L}$. In post monsoon it was observed minimum and in monsoon it was maximum.

The bicarbonate concentration varied between $23.52 \mathrm{mg} / \mathrm{L}$ to $30.14 \mathrm{mg} / \mathrm{L}$. In monsoon bicarbonate concentration was observed to maximum value and in post monsoon showed minimum value. In the study, the values of chloride were ranging between $4.30 \mathrm{mg} / \mathrm{L}$ to $11.36 \mathrm{mg} / \mathrm{L}$. The higher chloride value observed in monsoon season while in winter season it was observed less. In the present study Sulphate concentration varied between $0.20 \mathrm{mg} / \mathrm{L}$ to $5.20 \mathrm{mg} / \mathrm{L}$. The minimum as well as maximum value was observed in winter. During the study period dissolved oxygen varied between $5.20 \mathrm{mg} / \mathrm{L}$ to $9.78 \mathrm{mg} / \mathrm{L}$. Among the all values it was observed minimum in begging of post monsoon and maximum in off set of post monsoon. The biochemical oxygen demand values ranges between $0.25 \mathrm{mg} / \mathrm{L}$ to $3.50 \mathrm{mg} / \mathrm{L}$. Monsoon season shows higher value and winter shown less value of BOD. Chemical oxygen demand showed much variation. It ranges between $2.22 \mathrm{mg} / \mathrm{L}$ to 16.32 $\mathrm{mg} / \mathrm{L}$. The winter season showed minimum values of chemical oxygen demand were as post monsoon showed maximum value of chemical oxygen demand. The nitrate values varied between $0.46 \mathrm{mg} / \mathrm{L}$ to $1.72 \mathrm{mg} / \mathrm{L}$. Post monsoon showed the maximum value of nitrate where as minimum value observed in winter season. Phosphate value were nil at beginning of monsoon whereas post monsoon showed a maximum value of $0.49 \mathrm{mg} / \mathrm{L}$. During the monsoon, precipitation eroded the land containing fertilizer got mixed to water, may contribute the increased level of phosphate.

\section{REFERENCES}

[1] P.K.Goyal, 1996' 'Water Pollution Causes Effect and Control,' New Age International Publication, New Delhi

[2] A. Kaushik and C. P. Kaushik Perspective in Environmental Studies, New Age International Publishers. Second Edition. P. 14, 15 (2006).

[3] S. D.Muduli. (Et.al), Poll. Res. 25(4): P. 763,766 (2006).

[4] V. P Kudesia,. Water Pollution Pragati Prakashan. Meerut (1985).

[5] APHA (American Public Health Association $17^{\text {th }}$ Edition) (1989).

[6] D.B. Botkin, and Keller, Water Pollution and Treament, John Wiley and Sons, Inc New York-Chichester, E.A. Brisbane, Tronto Singapore, In Environmental Science Earth as a living planet p.398, 420(1995).

[7] R.K Trivedy,. and P.K Goel, Chemical and Biological Methods for Water Pollution Studies. Environmental publication, Karad, India (1984).

[8] WHO Guidelines for Drinking Water Quality Vol.2. Health Criteria and other supporting information. Genava. Mecmillan/Eeuteric-8000 (1984). 